\title{
Hormones and feed intake
}

By Clifton A. Baile* $\dagger$, Mary anne Della-Fera $\dagger^{*}$ and Carol L. McLaughlin†, Department of Clinical Studies at New Bolton Center, School of Veterinary Medicine, University of Pennsylvania, Kennet Square, PA 19348, USA

During the past 40 years, many of the known metabolites and hormones have been considered for possible roles in the control of feeding. In the development of this area of research, much attention was given to the relationship between obesity and diabetes (Mayer, 1955). This led to many experiments on the possible roles of insulin, glucose metabolism and feeding behaviours (Woods et al. 1974). The development of the concept of the glucostatic control of feeding generated interest in many phases of glucose homoeostasis and the insulin control system, especially as they are related to control of meal size and frequency. Research on the role of hypothalamic structures in energy balance regulation and feeding behaviour included many studies on the effects of both insulin and growth hormone (Bray \& York, 1979).

This brief review will be concerned primarily with current considerations for the roles of selected hormones in the control of feeding. Several peptides of the gastrointestinal (GI) tract and brain will be discussed, and the possible roles for the major pancreatic hormones, glucagon and insulin, will be reviewed.

\section{Gastrointestinal hormones}

For many years discussions on GI hormones were limited to three or four peptides, but it is now known that the GI tract is a large reservoir of peptides for which physiological actions have yet to be completely defined. In the several cases studied extensively, within a hormone family the activities are found in peptides of varying chain lengths. The peptides of the GI tract fall generally into two families, with members of a family having overlapping activities. Consideration of the peptides for roles in controlling behaviour is very much complicated by the above factors. While progress has been made in this area during the last decade, much remains to be discovered about the synthesis, production, release and actions of the various forms of the GI peptides.

The GI hormone with the most compelling evidence for a role in the control of feeding behaviour is cholecystokinin (CCK). In a convincing series of studies involving rats with gastric fistulas, which permitted them to ingest food but not digest or absorb it (thus allowing sham feeding), the percentage inhibition of food intake in a test meal after a $17 \mathrm{~h}$ fast was shown to be dose-dependent in a

Present addresses: "Monsanto Company (04C), 800 N. Lindbergh Boulevard, St. Louis, MO 63167, USA. TWashington University School of Medicine, $45^{66}$ Scott Avenue, St Louis, MO 631 ro, USA. 


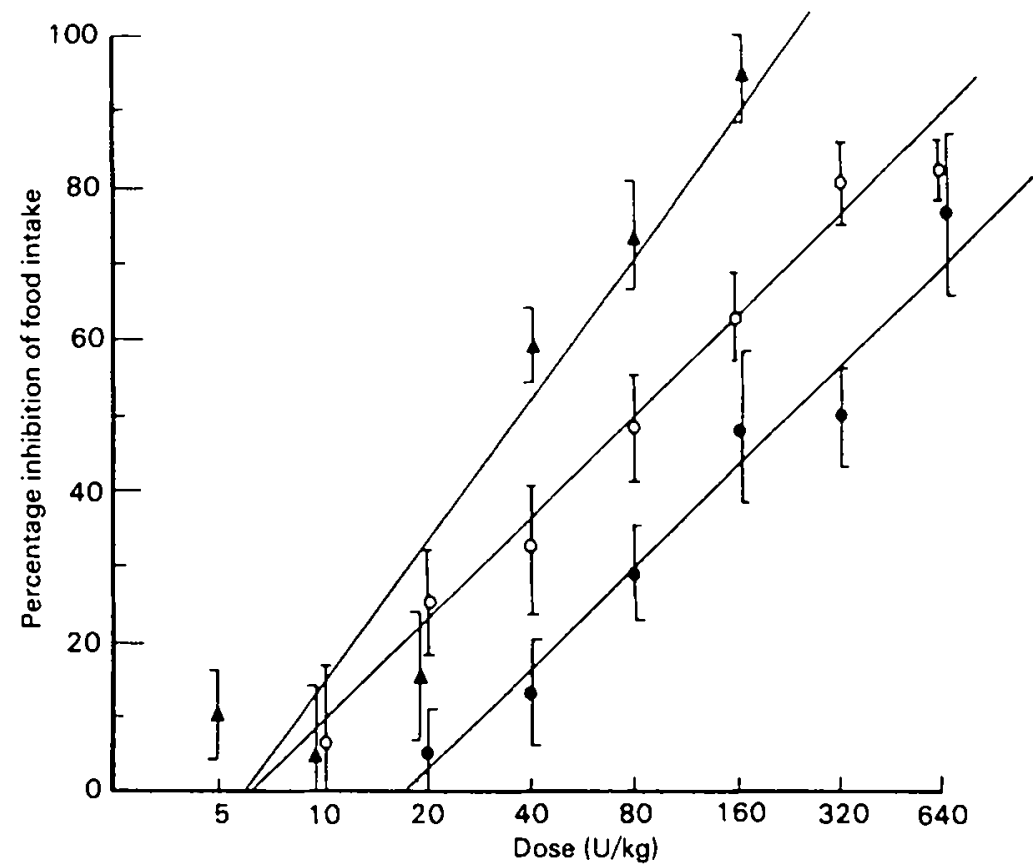

Fig. I. Percentage inhibition of food intake in rats, sham-fed a liquid diet in a $60 \mathrm{~min}$ test, is a function of the dose of impure $(20 \%)$ cholecystokinin $(\mathrm{CCK})(\Delta)$ and CCK octapeptide $(\mathbf{O})$, administered intraperitoneally, and CCK octapeptide $(O)$ administered intravenously. Points represent means and bars represent standard errors for data from at least five rats tested at each dose. (After Lorenz et al. 1979.)

logarithmically related manner when CCK was injected intraperitoneally (i.p.) or intravenously (i.v.) (Lorenz et al. 1979) (Fig. I). In the case of i.p. injections of the octapeptide of CCK (CCK-8), a frequently used form, a minimal reduction in sham feeding, approximately $10 \%$, was observed with a dose of $20 \mathrm{U} / \mathrm{kg}$. As much as $70 \%$ inhibition was obtained with a dose of $640 \mathrm{U} / \mathrm{kg}$. Slow i.v. injection of CCK-8 was four times as effective as a bolus i.p. injection on an equal dose basis.

The specificity of $\mathrm{CCK}$ has been clearly shown by comparing the effects of closely related peptides. The actions and receptor binding affinities of CCK-active peptides are known to be dependent on the presence of a sulphite group on the seventh amino acid, tyrosine (Steigerwalt $\&$ Williams, 198r). Feeding tests with the desulphated form of CCK-8 was only one-tenth as potent in inhibiting feeding as was the sulphated form (Lorenz et al. 1979). Other peptides with activities similar to those of CCK-8, e.g. CCK-33 and caerulein, also had similar inhibitory effects on intake (Gibbs et al. 1973).

The effect of endogenous CCK on feeding behaviour has been studied by several experimental approaches. Certain amino acids, particularly L-phenylalanine, in the lumen of the small intestine are known to cause release of CCK. Thus, when L-phenylalanine was infused intragastrically in monkeys, food intake decreased; D-phenylalanine was found to be ineffective (Gibbs et al. 1976). Brand \& Morgan (198I) obtained evidence for a negative feedback control of CCK release by trypsin 
in the lumen: decreased trypsin activity, produced by oral administration of a trypsin inhibitor, resulted in decreased CCK content in the intestinal mucosa (suggesting release of CCK), as well as increased secretion of pancreatic enzymes (a known effect of $\mathrm{CCK}$ ). These results suggest that by altering the level of trypsin activity in the gut, it is possible to change the amount of CCK released (Brand \& Morgan, 1981). It has been shown recently in our laboratory that trypsin inhibitor will decrease food intake in rats (Fig. 2) and trypsin supplements will increase intake (McLaughlin et al. 1983). In other studies, the administration of a trypsin inhibitor for $7 \mathrm{~d}$ resulted in sustained reduced intake and reduced body-weight (Peikin et al. 1982). Associated with these changes was an increased pancreatic weight, presumably due to increased $\mathrm{CCK}$ stimulation. This provides evidence for the possibility of long-term manipulation of feeding by influencing the CCK release pattern of the small intestine. We have also increased food intake in rats by injecting autoimmune-produced $\mathrm{CCK}$ antibody to sequester the endogenous $\mathrm{CCK}$ (Baile et al. 1983).

There is evidence that $\mathrm{CCK}$ receptors involved in the satiety response are located in the stomach wall, since gastric vagotomy eliminated the food intake inhibition of CCK in rats (Smith, Jerome, Cushin et al. 1981), while coeliac, hepatic, and coeliac plus hepatic vagotomies, or ventromedial hypothalamic lesions, failed to significantly reduce the CCK feeding effect. Although the CCK feeding response is similar to that in rats-including man (Kissileff et al. 198I),
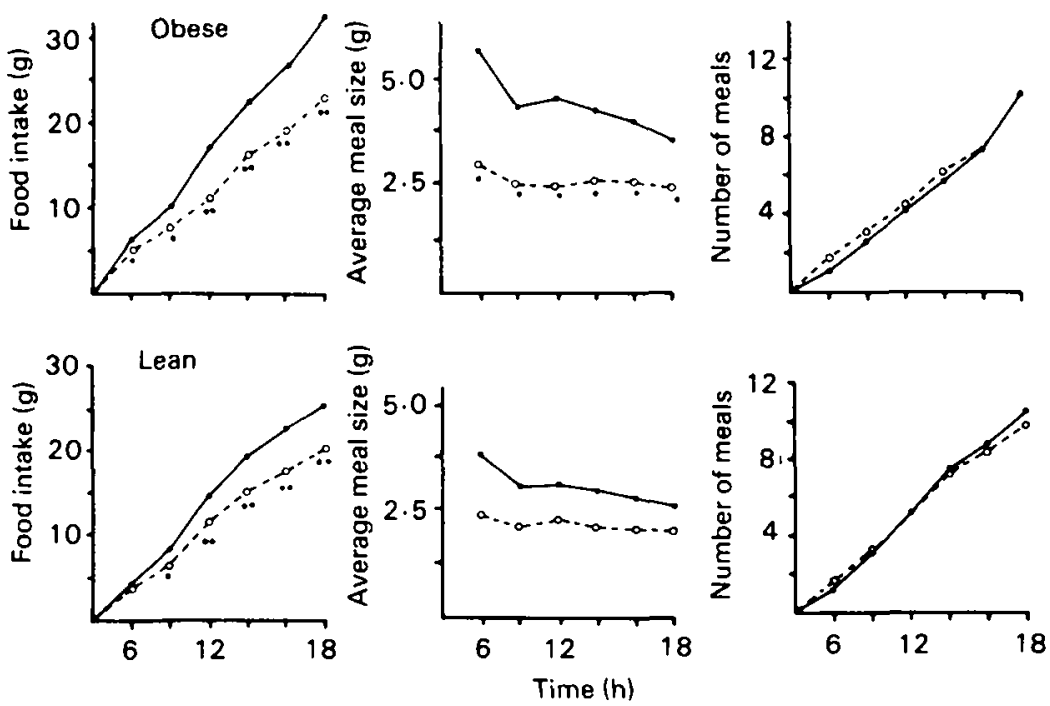

Fig. 2. Feeding behaviour response of 6 -h-fasted Zucker obese and lean rats for $18 \mathrm{~h}$ after intragastric administration of $2.0 \mathrm{ml}$ water $/ \mathrm{kg}$ (——) or $200 \mathrm{mg}$ trypsin inhibitor (TI; $N, N$-dimethyl-carbamoyl $4-$-guanidino-benzoyloxy - phenylacetate methane sulphate/kg $(---)$ ). The response to TI was significantly different from the response to water: Student's paired $t$ test $\bullet P 0.05$ and $* P<0.01$. (After McLaughlin et al. 1983 ). 
cats (Mendel et al. 1980), rabbits (Houpt et al. 1978) and pigs (Anika et al. r98I)-it remains to be shown that the response in species other than the rat is also dependent on gastric vagus innervation.

The controversy over the blood concentrations of $\mathrm{CCK}$ required to reduce feeding, compared with those that may exist postprandially, remains to be resolved. While several CCK assays have been reported for the measurement of plasma CCK (e.g. Rayford et al. 1978; Byrnes et al. 1981; Walsh et al. 1982), the values still are questionable due to either the complexity or the lack of specificity of the assays. The possibility that the intestinal mucosa releases CCK in several forms adds a complicating factor to the assay systems.

In obese animals and man, it is proposed that the characteristic increased meal size may be due to decreased sensitivity to satiety factors. Work in our laboratory has shown that genetically obese rodents are less susceptible to the food intake inhibitory effect of CCK than are their lean littermate controls (McLaughlin \& Baile, 1980). This decreased sensitivity is more evident in rats of $3-4$ weeks old than in older rats, and may be involved in the hyperphagia which is more pronounced in these younger rats. Thus, there is support for the proposal that lack of sensitivity to CCK may be related to the larger meals of the obese rats.

The food-intake responses to CCK have been studied for nearly a decade now, and much remains to be done to establish that satiety is a physiological action of CCK. Criticism of several of the reports has included the suggestion that the decreased intake is the result of malaise (Deutsch \& Wang, 1977). Strong arguments have been presented that make this explanation unlikely (Smith \& Gibbs, 1981). Clearly, CCK remains a strong candidate for a role in satiety.

Bombesin, a tetradecapeptide, stimulates the pancreas to secrete enzymes in much the same way as CCK, although it is known to act on a different receptor. This peptide has an unusual history in that it was first isolated from amphibian skin (Erspamer \& Melchiorri, I 973). Subsequently, bombesin-like immunoreactivity has been found in mammalian brain and gut (Dockray, 1976; Polak et al. 1977). Bombesin was shown to suppress feeding in rats at doses nearly equal in mass to those required for CCK (Gibbs et al. 1979). Ventromedial hypothalamically lesioned rats also responded to bombesin in a manner similar to the intact rats. While most of the responses to bombesin resemble those to $\mathrm{CCK}$, a striking difference is the finding that bombesin remains effective in suppressing feeding in vagotomized rats (Smith, Jerome \& Gibbs, 1981), while CCK has no effect.

Bombesin has been reported to cause malaise in rats (Deutsch \& Parsons, I98I), but other studies have failed to show such effects (e.g. West et al. I 982 ). Bombesin is proposed to cause release of CCK from the intestine, but this is not likely to be required for the feeding response since, as mentioned previously, bombesin decreases feeding in the vagotomized rat and CCK does not.

Bombesin-like immunoreactivity increases in plasma following a meal (Brown \& Vale, 1979), but the plasma concentrations caused by doses required to reduce feeding have not been reported. It is thus not known if the feeding responses to 
bombesin are related to physiological concentrations following a meal. Bombesin remains an intriguing peptide, but there is still much to be done to establish a physiological role.

Somatostatin is another tetradecapeptide that is found in both the brain and GI tract, as well as in other organs, and it has been proposed to play a role in satiety. Somatostatin inhibits the actions of many of the known peptide hormones including those of the endocrine pancreas and GI tract, e.g. insulin (Brazeau et al. 1973), glucagon (Guillemin \& Gerich, 1976) and gastrin (Bloom et al. 1974). CCK injections cause an increase in plasma somatostatin concentration, thus somatostatin could potentially contribute to the actions of CCK on feeding behaviour. Plasma somatostatin concentration is known to increase following a meal (Guillemin \& Gerich, 1976).

In experiments with both rats and baboons, somatostatin reduced food intake (Lotter et al. 1981). The rats, given as little as ro ng/kg i.p., reduced their intake but failed to show a depression in feeding when $100 \mathrm{ng}$ were given in the lateral cerebral ventricles (LV). Baboons were also sensitive to only the i.p. injections of somatostatin. Although little is known of the mechanism of action of somatostatin on feeding behaviour, the vagus apparently mediates the response, since vagotomized rats failed to reduce their food intake following somatostatin injections (Levine \& Morley, I982). Somatostatin is already known to have a wide range of actions and may indeed be a component in satiety.

Other GI peptides have been tested for effects on feeding behaviour under conditions similar to those for the previously mentioned peptides. Several of these were shown to have no significant effect on feeding, e.g. gastrin, secretin and gastric inhibitory polypeptide (Lorenz et al. 1979). While substance P (Morley \& Levine, $1980 b$ ) and neurotensin have been reported to decrease feeding (Smith \& Gibbs, $198 \mathrm{I}$ ), little additional information on the response is available. Since the GI-tract mucosa is such a rich reservoir of peptides, it is likely that still others that influence feeding behaviour will be found. The relationships of the function of the GI tract, metabolism and behaviour are undoubtedly complex and are still poorly understood.

\section{Brain peptides}

There is increasing recognition that brain peptides play important roles in integrating behaviours. Recently, much attention has been focused on the role of neuropeptides in the control of feeding behaviour. Four brain peptides are being considered as candidates in the physiological system involved in the control of feed intake and regulation of energy balance: $\mathrm{CCK}$ peptides, opiate peptides, bombesin, and calcitonin.

$\mathrm{CCK}$, classically known as a GI hormone, appears to have an equally important role as a brain neurohormone or neurotransmitter. $\mathrm{CCK}$ peptides have been demonstrated in the brain tissue of numerous mammalian and non-mammalian species. At least five forms of CCK appear to be present in the brain: a component larger than CCK-39 and a component similar in size to CCK-39, CCK-12, CCK-8 
and $\mathrm{CCK}_{-4}$ (which is the same as gastrin-4) (Larsson \& Rehfeld, 1979; Rehfeld et al. 1979). The predominant form, CCK-8, appears to result from the processing of larger molecular forms (Goltermann et al. 1980). CCK peptides, as well as CCK receptors, have a specific regional distribution in the brain (Rehfeld, 1978; Innis \& Snyder, 1980; Saito et al. 1980; Beinfeld et al. 1981). Unlike most other brain peptides, the highest concentrations of $\mathrm{CCK}$ and $\mathrm{CCK}$ receptors occur in the cortex, but substantial amounts of CCK -8 have also been shown to be present in the periaqueductal gray, dorsomedial hypothalamus and hippocampus.

The original interest in CCK's potential brain effects stemmed from proposals of central receptors for peptides of peripheral origin; thus the satiety effect of intestinal CCK was hypothesized to be mediated by hypothalamic receptors. With the discovery that CCK peptides are actually synthesized in neurons of the brain, the interest of some investigators switched to the possibility that brain CCK peptides may act as neurohormones in the central nervous system circuitry involved in feeding behaviour. Early studies by Stern et al. (1976) and Maddison (1977) indicated that CCK peptides administered centrally to rats acted directly on brain structures to reduce feeding. Other investigators, however, have been less successful in showing that rats respond to central administration of CCK (Della-Fera \& Baile, 1979; Grinker et al. 1980). Also controversial is the finding of reduced levels of $\mathrm{CCK}$ in the brains of genetically obese compared with lean mice

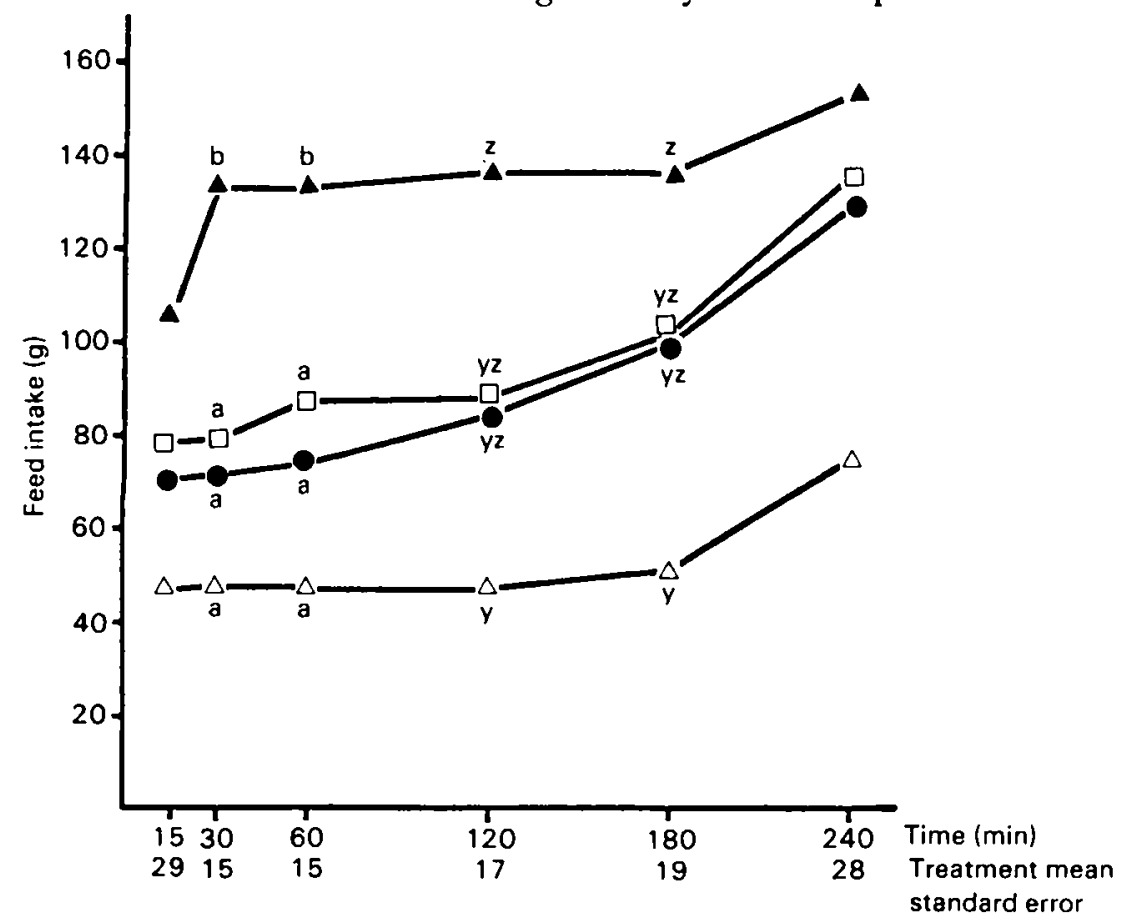

Fig. 3. Food intake of eight 2-h-fasted sheep injected for $3 \mathrm{~h}$ with cholecystokinin octapeptide (CCK-8) into the lateral cerebral ventricle. Synthetic cerebrospinal fluid ( 4 ), $0.01 \mathrm{pmol}$ CCK-8/ $\mathrm{min}(\square), 0.04 \mathrm{pmol} \mathrm{CCK}-8 / \mathrm{min}(0), 0.159 \mathrm{pmol} \mathrm{CCK}-8 / \mathrm{min}(\triangle)$. Feed was returned $15 \mathrm{~min}$ after the beginning of the injection (zero time). Treatment means without a common letter were significantly different: ab, $P<0.05 ;$ yz, $P<0.01$. (After Della-Fera \& Baile, 1980b.) 
(Straus \& Yalow, 1979) and fasted compared with fed mice (Straus \& Yalow, 1980). In contrast to the inconsistent feeding responses of $\mathrm{CCK}$ injected in the brain of rats, food intake is reduced following injection of bombesin in the LV in the rat (Gibbs et al. 1981; Morley \& Levine, $1981 b$ ), as well as in sheep (Baile \& Della-Fera, 198I) and pigs (Parrott \& Baldwin, 1982).

In sheep (Della-Fera \& Baile, 1979), pigs (Parrott \& Baldwin, 1981) and golden hamsters (M. E. Miceli and C. W. Malsbury, personal communication), there is good evidence that brain $\mathrm{CCK}$ is directly involved in the control of feeding behaviour. When administered as a continuous injection into the $\mathrm{LV}$ of sheep, amounts of CCK-8 approaching the physiological range caused significant decreases in feeding (Fig. 3). The effect of brain CCK-8 appears specific for feeding behaviour, since neither water intake nor body temperature is affected (Della-Fera \& Baile, $1980 a$ ).

Sheep fasted for an increasing time required increasing doses of CCK-8 to produce equivalent decreases in feed intake; thus, CCK-8-induced suppression of feeding interacts in a corrective manner with the energy deficit of the animal. However, under certain conditions, the effect of CCK- 8 on feeding was prolonged; e.g. in sheep adapted to a 6-h feeding period/d injection of CCK-8 during one 6-h period resulted in decreased cumulative feed intake for up to $2 \mathrm{~d}$. Thus, it appears that more chronic elevations of CCK- 8 in the central nervous system could result in negative energy balance (Della-Fera \& Baile, $1980 b$ ).

The strongest evidence for a role for brain CCK- 8 in satiety in sheep comes from the results of studies in which CCK-8 antibody solutions were administered into the LV of satiated sheep (Fig. 4). CCK-8 antisera from two different rabbits

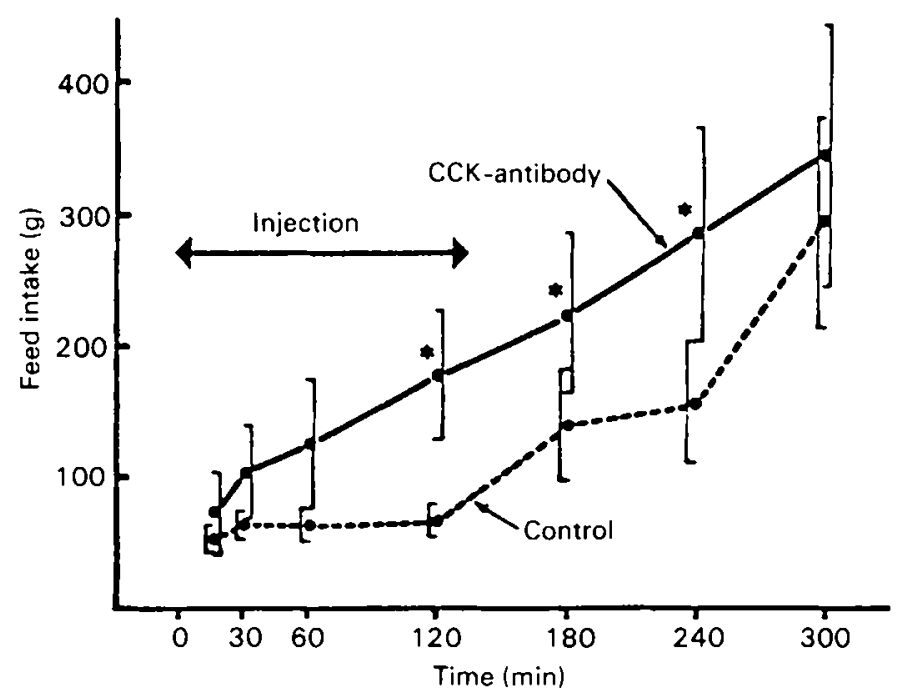

Fig. 4. Food intake of satiated sheep during continuous lateral ventricular injection of cholecystokinin antibody-I at a cholecystokinin octapeptide binding capacity of $24 \mathrm{mg} / 0.03 \mathrm{ml}$ $(-)$ and of control rabbit serum in synthetic cerebrospinal fluid $(---)$. The injections were delivered at a rate of $0.03 \mathrm{ml} / \mathrm{min}$ for $2 \mathrm{~h}$; the values represent means and the bars standard errors for nine sheep in each group. $* P<0 \cdot 10$. (After Della-Fera \& Baile, I981.) 
caused significant increases in feeding in a dose-dependent manner. These results, in conjunction with more recent findings suggesting that CCK-8 is actively taken up from the CSF, support the hypothesis that during feeding, CCK- 8 is released into the ventricular system and is subsequently transported to brain site(s) of action.

The studies on central nervous system effects of CCK peptides in pigs and hamsters are not as extensive as those in sheep; however, as in sheep, LV injections of CCK-8 in fasted pigs reduced feeding in a dose-dependent manner without affecting drinking behaviour (Parrott \& Baldwin, I98I). Studies in hamsters have also shown that effective LV doses are lower than effective peripheral doses (M. E. Miceli and C. W. Malsbury, personal communication).

The mechanism of action of central CCK's effect on feeding behaviour is unclear, and the problem is complicated by findings that centrally administered CCK peptides can cause changes in GI function (Della-Fera \& Baile, 1980a) and secretion of certain hormones (Della-Fera \& Baile, I98I). In addition, it is possible that some of the effects of brain CCK are mediated either through the release of other brain peptides, e.g. calcitonin (Care et al. 1971), or neurotransmitters, e.g. norepinephrine (McCaleb \& Meyers, 1980 ). It is possible that the many actions of brain CCK-8 are related to a central regulatory function of this peptide, but much more information is needed before a unifying hypothesis can be proposed.

The recent discovery of opiate receptors and endogenous opiate peptides in the brain has given rise to obvious questions on their physiological significance. Information generated thus far has led to suggestions of opiate involvement in pain (Terenius, 1978), stress (Amir et al. 1980), learning and memory processes (Riley et al. I980), certain psychiatric disorders (Bloom et al. 1976), hibernation (Margules et al. 1979), ingestive behaviour (Morley, 1980) and body-weight regulation (Mandenoff et al. I982). The research on opiate involvement in the central nervous system control of feeding behaviour is extensive and highly suggestive of a physiological role for an opiate receptor system acting in the initiation of feeding.

A wide variety of opiate agonists and aritagonists have been tested in an attempt to determine the mechanisms involved in opiate-induced feeding, as well as to determine which class or classes of opiate receptors are responsible for mediating this effect. Both exogenous and endogenous opiate compounds have been shown to stimulate feeding after either intracerebroventricular (icv) or intracerebral injection. For example, beta endorphin, D-ala ${ }^{2}$-met-enkephalinamide (Table I), alpha neoendorphin, and dynorphin all stimulated feeding in satiated rats or sheep after icv injection (McLean \& Hoebel, I980; Baile et al. I981; McKay et al. 198I; Morley \& Levine, 1981a). By taking advantage of the fact that different opiate agonists bind different classes of receptors with varying affinities, it has been possible to draw some tentative conclusions concerning the involvement of specific receptor systems in the feeding response. Both kappa and mu opiate receptors appear to be particularly important in the hyperphagia response, since opiates that are relatively specific for either of these types of receptors are highly effective in 
Table I. Food intake response $(\mathrm{g})$ of satiated sheep $(50 \mathrm{~kg}$ ) following injections $(0.03 \mathrm{ml} / \mathrm{min}$ for $90 \mathrm{~min})$ of $\mathrm{D}-$ ala $^{2}$-met-enkephalinamide into the lateral cerebral ventricle (after Baile et al. $198 \mathrm{I}$ )

(Mean values with their standard errors for six sheep)

\begin{tabular}{|c|c|c|c|c|c|c|c|c|}
\hline \multirow[b]{3}{*}{ Time (min) } & \multicolumn{8}{|c|}{ Dose $\mathrm{D}$-ala ${ }^{2}$-met-enkephalinamide (nmol/min) } \\
\hline & \multicolumn{2}{|c|}{ O } & \multicolumn{2}{|c|}{26} & \multicolumn{2}{|c|}{$\underbrace{5 \mathrm{I}}$} & \multicolumn{2}{|c|}{102} \\
\hline & Mean & SE & Mean & SE & Mean & SE & Mean & $\mathrm{SE}$ \\
\hline $0-30$ & 27 & 12 & 62 & $2 \mathrm{I}$ & 74 & 26 & 62 & 26 \\
\hline $0-60$ & 27 & $12^{x}$ & 124 & $2 \mathrm{I}^{y}$ & 100 & $26^{x, y}$ & 132 & $25^{y}$ \\
\hline $0-90$ & 28 & $13^{x}$ & 125 & $2 \mathrm{r}^{y}$ & 144 & $3^{8^{y}}$ & 151 & $3 a^{y}$ \\
\hline $0-120$ & I I 3 & 27 & $13^{6}$ & 25 & 162 & 43 & 192 & $3^{8}$ \\
\hline $0-180$ & 125 & $26^{a}$ & 157 & $19^{a, b}$ & 222 & $27^{b}$ & 227 & $45^{b}$ \\
\hline
\end{tabular}

${ }_{a, b}$ Means with different superscripts are significantly different, ANOVA, $P<0.05$. $x, y$ Means with different superscripts are significantly different, ANOVA, $P<0.01$.

inducing feeding (Yim et al. 1980; Morley \& Levine, I981 $a$; Sanger \& McCarthy, $198 \mathrm{I}$; Tepperman et al. 1981; Lowy \& Yim, 1983).

Naloxone, a highly specific antagonist of mu and sigma opiate receptors decreases feeding after food deprivation in a variety of species, e.g. rats and mice (Holtzman, 1974; Brown \& Holtzman, 1979), sheep (Baile et al. 1981), guinea-pigs (Schulz et al. 1980), rabbits (Sanger \& McCarthy, 1981) and cats (Foster et al. I98I). In addition to their suppressive effect on normal feeding behaviour, opiate antagonists attenuate feeding associated with other types of hyperphagic conditions, such as tail-pinch-induced feeding (Lowy et al. 1980; Morley \& Levine, $1980 a$ ). Because both naloxone and naltrexone block the feeding induced by exogenous administration of opiate agonists (Grandison \& Guidotti, 1977; Baile et al. $198 \mathrm{I}$; Morley \& Levine, $198 \mathrm{I} a$ ), as well as the fact that the anorexic effect of opiate antagonists are dose-related and stereospecific, direct interaction with opiate receptors is likely (Lowy et al. $198 \mathrm{I}$ ).

Endogenous opiate peptides have also been implicated directly in the regulation of body-weight. Margules et al. (1978) reported that genetically obese rats and mice had higher levels of pituitary beta endorphin than lean littermate controls. The obese animals were also reported to be more sensitive to the anorexic effect of naloxone; thus the suggestion was made that a chronic elevation of beta endorphin resulted in hyperphagia and obesity in these animals. Although this interpretation has been disputed by Rossier et al. (1979), whose findings suggested that the elevated pituitary beta endorphin was a result rather than a cause of the obesity, more recently Recant et al. (1980) reported that elevated plasma levels of beta endorphin were present in genetically obese mice as early as 4 weeks of age. Significant reductions of hypothalamic, but not pituitary, beta endorphin levels have been found after 2 or $3 \mathrm{~d}$ of food deprivation (Gambert et al. 1980). 
These studies provide only indirect evidence that opiate peptides are involved in body-weight regulation; however, in a recent study by Mandenoff et al. (1982), chronic reduction in body-weight occurred in rats given a long-acting form of naloxone. The authors claimed that the decrease in body-weight was due to both a decrease in food intake and an increase in energy expenditure.

Neither the site of the opiate receptors involved in the feeding response nor the mechanism of action of opiates in eliciting feeding is known. There is some evidence for an interaction between opiates and dopamine in the nigrostriatal pathway (Pollard et al. 1978; Urwyler \& Tabakoff, 1981; Morley, Levine, Brown et al. 1982) and Morley et al. (1981) suggested that glucose levels are important in regulating the sensitivity of the opiate receptors involved in the feeding response. There is probably no reason to believe, however, that opiate peptides are solely responsible for the initiation of feeding, but it is likely that they can play a major role under certain circumstances.

Calcitonin, a peptide hormone secreted by the thyroid, is primarily involved in skeletal calcium metabolism. It is also present in the hypothalamus and cerebrospinal fluid (Becker et al. 1980) and is known to bind to sites in the hypothalamus (Rizzo \& Goltzman, 1981). Calcitonin has been shown to reduce food intake in man, monkeys, rats (Perlow et al. 1980) and mice (Morley, Levine, Grace et al. 1982) after parenteral administration, but in more recent studies employing LV injection of calcitonin, only $1 / 1000$ th of the parenteral dose was required to cause a similar reduction in feeding $(4 \mathrm{I} 6 \mathrm{pg} / \mathrm{rat}$, icv $v .2 \mu \mathrm{g} / \mathrm{kg}$ body-weight, i.p.; Levine \& Morley, I98I). A much larger dose, $4 \mathrm{I} 6 \mathrm{ng}$ injected intraventricularly, completely suppressed feeding in rats for $8 \mathrm{~h}$ during the nocturnal cycle, and intakes were less than half those of the controls for $32 \mathrm{~h}$. None of the other peptides tested in the brain have given such a sustained response. $\mathrm{CaCl}_{2}$ injected into the cerebral ventricles was shown to elicit feeding in rats (Myers et al. 1972), sheep (Seoane et al. 1975) and pigs (Baldwin et al. 1975), and calcitonin may be acting on the same hypothalamic system. Levine \& Morley ( 1981 ) have in fact shown that calcitonin can prevent the feeding response elicited by $\mathrm{CaCl}_{2}$ in rats. Because calcitonin also reduced ${ }^{45} \mathrm{Ca}^{2+}$ uptake in hypothalamic tissues, they suggested that this accounted for the blocking of the $\mathrm{CaCl}_{2}$-induced feeding.

While much more work is required to show that calcitonin indeed has a physiological role in the control of feeding, the evidence to date is supportive. Other work showing that calcitonin concentrations in the plasma increased during meals (Talmage et al. 1975) and that plasma CCK may cause release of calcitonin (Care et al. 1971) also lends support to the proposed role for calcitonin.

\section{Pancreatic hormones}

The primary pancreatic hormones insulin and glucagon have recently received special attention for roles in the control of feeding behaviour and regulation of energy balance. As pointed out previously, these hormones have long been 
considered candidates for roles in these systems, but new experimental approaches have made some of the contentions stronger.

Glucagon has been implicated as a satiety factor as a result of its hyperglycaemic effect (Schulman et al. 1957). In studies with rats, glucagon injected prior to a meal reduced meal size and produced normal satiety behaviour patterns (Geary \& Smith, 1982a). Glucagon doses required to reduce meal size caused changes in hepatic metabolism that are also present at the end of normal meals, e.g. reduced liver glycogen content (Langhans et al. 1982), but in several instances it has been shown that the hyperglycaemic response to glucagon is not sufficient to cause the feeding response (Geary \& Smith, I $982 b$ ). While plasma concentrations of glucagon have been shown to increase during meals (DeJong et al. 1977), the actual changes that followed the injections of glucagon in the feeding experiments have not been reported.

In the case of glucagon the most compelling evidence for its role as a satiety factor is a recent report that glucagon antibody injections in rats will cause increased feeding (Langhans et al. 1982). The rats were injected i.p. with the specific pancreatic glucagon antibody at the beginning of the first meal of the dark phase and following a $12 \mathrm{~h}$ fast. Compared with food intake following injection of rats with normal serum, the rats injected with glucagon antibody serum increased their meal size $63 \%$ and meal duration $74 \%$. It is concluded that the antibody sequestered the glucagon released during the meal and thus removed what apparently is an essential component for satiety. Supporting this conclusion were the additional findings that hepatic vein blood glucose and unbound glucagon concentrations during the meal were reduced compared with those of control rats (E. Scharrer, personal communication).

While it is not yet clear which aspects of glucagon's several metabolic effects are responsible for the satiety effect, apparently an intact vagus is required (Martin \& Novin, 1977), and the associated hyperglycaemia may not be sufficient for the induction of satiety (Geary \& Smith, 1982b). Clearly, glucagon currently is the single strongest candidate for a peripheral satiety factor.

The suggested roles for insulin's involvement in the control of food intake have been many over the last 30 years. Insulin injections which cause severe hypoglycaemia clearly cause feeding, but they are also likely to be associated with a pathological state (Brandes, 1977). Hyperinsulinaemia and hyperphagia, but not hypoglycaemia, frequently occur with the development of obesity (Jeanrenaud, 1979). The causes for these associations are not clear, but insulin resistance is a common factor. Hypoinsulinaemia does not result in anorexia as might be predicted if insulin were essential to initiate feeding. There may be opposing effects on feeding of acute and persistent changes in plasma insulin concentration, and a recent proposal may help in the understanding of the feeding responses to integrated changes in plasma insulin concentrations over time.

Insulin is proposed by Porte $\&$ Woods ( $198 \mathrm{r}$ ) to be a body adiposity signal. They have classified factors which influence the control of feeding into two categories. One category includes the factors discussed above which cause changes in feeding 
behaviour independent of the state of body stores. A second includes factors which are responsive to the size of the adipose mass. This second category provides a means for coupling weight or energy-balance regulation to meal feeding. They propose that insulin is such a hormone signal. The basis for the proposal includes the many observations that plasma insulin concentration increases with the severity of adiposity. A second important aspect considered is that because insulin concentration changes rapidly and frequently within a $24 \mathrm{~h}$ period and reflects a variety of stimuli, some means is required for obtaining an integrated response with a relatively slow time constant. They propose that the insulin of the cerebrospinal fluid (CSF) has the required characteristics. The CSF insulin concentrations, which are approximately $20 \%$ of plasma concentrations, change with plasma concentrations, although at a much slower rate. Insulin in CSF has a half-life of hours rather than minutes, although it is apparently of plasma origin.

A primary finding in support of the hypothesis is that insulin injections into the $\mathrm{LV}$ at the doses of 10 or $100 \mu \mathrm{U} / \mathrm{kg}$ per $\mathrm{d}$ in baboons reduced both food intake and body-weight (Woods et al. 1979). The injections of insulin were continuous over I4 $d$ and the effects were greater near the end of the period than initially. The response with the $10 \mu \mathrm{U} / \mathrm{kg}$ per $\mathrm{d}$ was especially remarkable since the slow rate of injection would change the CSF insulin concentrations only slightly over the $24 \mathrm{~h}$ period. Injections of glucagon at equal molar rates had no effect, and thus the response was not a nonspecific peptide response.

Insulin may thus play a role in the maintenance of body-weight by action in the brain. While it is known that insulin receptors exist in hypothalamic structure associated with feeding, it is not yet clear how the insulin in the CSF acts. While much remains to be done to prove the association of CSF insulin and energy-balance regulation, the hypothesis is intriguing and the data obtained to date are supportive; therefore, both of the major pancreatic hormones are likely to have a role in the control of feeding behaviour and regulation of energy balance.

\section{Summary}

During the several decades that hormones have been considered for roles in the control of feeding, certain ones have gained special attention, although the role assigned to any one hormone has varied from time to time. Three classes of hormones have been considered in this review: gastrointestinal, brain, and pancreatic. Of these classes, two have obtained the most compelling evidence for a physiological role in the control of feeding. $\mathrm{CCK}$, an intestinal and brain hormone, appears to be involved in satiety. Glucagon of pancreatic origin appears also to play an important role in satiety. These hormones, when sequestered by a specific antibody, cause a delay in satiety and thus increase food intake.

Insulin, another pancreatic hormone, has been considered for several roles in the control of feeding. Recently, attention has been given to the possibility that insulin of the CSF provides an integrated link between the metabolic state of the adipose tissue and the brain structures concerned with the control of feeding. Thus, insulin 
may be a primary hormone involved in the maintenance of energy balance or of body-weight.

Finally, brain opiate peptides, e.g. dynorphin, are very likely involved in the transmission of information concerned with the interaction of feeding and maintenance of energy balance. Clearly, hormones play primary roles in the control of feeding behaviour and the regulation of energy balance, but much remains to be done to establish their specific actions or components of the associated physiological systems.

The work from the author's laboratory was supported in part by Grants-In-Aid from NIH (NSi 7670), (MH-35746), and the University of Pennsylvania Research Foundation.

\section{REFERENCES}

Amir, S., Brown, Z. W. \& Amit, Z. (1980). Neurosci. Biobehav. Rev. 4, 77.

Anika, S. M., Houpt, T. R. \& Houpt, K. A. (I98I). Am. F. Physiol. 240, 3 Io.

Baile, C. A. \& Della-Fera, M. A. (1981). Fedn Proc. Fedn Am. Socs exp. Biol. 40, 308.

Baile, C. A., Keim, D. A., Della-Fera, M. A. \& McLaughlin, C. L. (1981). Physiol. Behav. 26, rorg.

Baile, C. A., McLaughlin, C. L. \& Buonomo, F. C. (1983). Fedn Proc. Fedn Am. Socs exp. Biol. $42,392$.

Baldwin, B. H., Grovum, W. L., Baile, C. A. \& Brobeck, J. R. (1975). Pharm. Biochem. Behav. 3,915 .

Becker, K. L., Silva, O. L., Post, R. M., Ballenger, J. C., Carman, J. S., Snider, R. H. \& Moore, C. F. (1980). Brain Res. 194, 598.

Beinfeld, M. C., Meyer, D. K., Eskay, R. L., Jensen, R. T. \& Brownstein, M. J. (1981). Brain Res. 212, 5 I.

Bloom, F., Segal, D., Ling, N. \& Guillemin, R. (1976). Science 194, 630.

Bloom, S. R., Mortimer, C. H., Thorner, M. O., Besser, G. M., Hall, R., Gomez-Pan, A., Roy, V. M., Russel, R. C. G., Coy, D. H., Kasten, A. J. \& Schally, A. V. (1974). Lancet ii, I 106.

Brand, S. J. \& Morgan, R. G. H. (1981). F. Physiol. 319, 325.

Brandes, J. S. (1977). Physiol. Behav. 18, 1095.

Bray, G. A. \& York, D. A. (1979). Physiol. Rev. 59, 719.

Brazeau, P., Vale, W., Burgus, R., Long, N., Butcher, M., Rivier, J. \& Guillemin, R. (1973). Science 179, 77 .

Brown, D. R. \& Holtzman, S. G. (1979). Pharm. Biochem. Behav. I1, 567.

Brown, M. \& Vale, W. (1979). Trends Neurosci. 2, 95.

Byrnes, D. J., Henderson, L., Borody, T. \& Rehfeld, J. F. (1981). Clinica chim. Acta r Ix, 81 .

Care, A. D., Bruce, J. B., Boelkins, J., Kenny, A., Connaway, H. S. \& Anast, C. S. (1971). Endocrinology 89, 262.

DeJong, A., Strubbe, J. M. \& Steffens, A. B. (1977). Am. Y. Physiol. 233, 380.

Della-Fera, M. A. \& Baile, C. A. (1979). Science 206, 47 I.

Della-Fera, M. A. \& Baile, C. A. (1980a). Peptides r, 5 I.

Della-Fera, M. A. \& Baile, C. A. (1980b). Physiol. Behav. 24, 943.

Della-Fera, M. A. \& Baile, C. A. (1981). Soc. Neurosci. Abstr. 7,33 .

Della-Fera, M. A., Baile, C. A., Schneider, B. S. \& Grinker, J. A. (I98I). Science 21 2, 687.

Deutsch, J. A. \& Parsons, S. L. (I981). Behav. Neural. Biol. 31, 110.

Deutsch, J. A. \& Wang, M. L. (1977). Nature, Lond. 266, 196.

Dockray, G. J. (1976). Nature, Lond. 264, 568.

Erspamer, V. \& Melchiorri, P. (1973). Pure Appl. Chem. 35, 463 . 
Foster, J. A., Morrison, M., Dean, S. J., Hill, M. \& Frenk, H. (1981). Pharm. Biochem. Behav. 14, 419 .

Gambert, S. R., Garthwaite, T. L., Pontzer, C. H. \& Hagen, T. C. (I980). Science $210,1271$.

Geary, N. \& Smith, G. P. (1982a). Physiol. Behav. 28, 3 1 3.

Geary, N. \& Smith, G. P. (1982b). Peptides 3, 163 .

Gibbs, J., Falasco, J. D. \& McHugh, P. R. (I976). Am. F. Physiol. 230, 15.

Gibbs, J., Fauser, D. J., Rowe, E. A., Rolls, B. J., Rolls, E. T. \& Maddison, S. P. (1979). Nature, Lond. 282, 208.

Gibbs, J., Kulkosky, P. J. \& Smith, G. P. (198I). Peptides 2, 179.

Gibbs, J., Young, R. C. \& Smith, G. P. (1973). F. comp. Physiol. Psych. 84, 488.

Goltermann, N. R., Rehfeld, J. F. \& Roigaard-Petersen, H. (1980). F. Neurochem. 35, 479.

Grandison, L. \& Guidotti, A. (1977). Neuropharmacology 16, 533.

Grinker, J. A., Schneider, B. S., Ball, G., Cohen, A., Strohmayer, A. \& Hirsh, J. (1980). Fedn Proc. Fedn Am. Socs exp. Biol. 39, 5oI.

Guillemin, R. \& Gerich, J. E. (1976). Ann. Rev. Med. 27, 379.

Holtzman, S. G. (1974). Y. Pharm. exp. Ther. 189, 5 I.

Houpt, T. R., Anika, S. M. \& Wolff, N. C. (1978). Am. Y. Physiol. 235, 23.

Innis, R. B. \& Snyder, S. H. (1980). Eur. F. Pharm. 65, 123 .

Jeanrenaud, B. (1979). Diabetologia 1 7, 133.

Kissileff, H. R., Pi-Sunyer, F. X., Thornton, T. \& Smith, G. P. (1981). Am. F. clin. Nutr. 34, 154 .

Langhans, W., Geary, N. \& Scharrer, E. (1982). Am. F. Physiol. 243, 450.

Langhans, W., Zieger, V., Scharrer, E. \& Geary, N. (1982). Science $218,894$.

Larsson, L-I. \& Rehfeld, J. F. (1979). Brain Res. 165, 201.

Levine, A. S. \& Morley, J. E. (1981). Brain Res. 222, 187.

Levine, A. S. \& Morley, J. E. (1982). Pharm. Biochem. Behav. 16, 897.

Lorenz, D. N., Kreielsheimer, G. \& Smith, G. P. (1979). Physiol. Behav. 23, 1065.

Lotter, E. C., Krinsky, R., McKay, J. M., Treneer, C. M., Porte, D. \& Woods, S. C. (1981). J. comp. Physiol. Psychol. 95, 278.

Lowy, M. T., Maickel, R. P. \& Yim, G. K. W. (1980). Life Sci. 26, 2 1 3.

Lowy, M. T., Starkey, C. \& Yim, G. K. W. (1981). Biochem. Behav. 15, 591 .

Lowy, M. T. \& Yim, G. K. W. (1983). Psychopharmacology. (In the Press.)

McCaleb, M. L. \& Meyers, R. D. (I g80). Peptides I, 47.

McKay, L. D., Kenney, N. J., Edens, N. K., Williams, R. H. \& Woods, S. C. (I98r). Life Sci. 29, 1429 .

McLaughlin, C. L. \& Baile, C. A. (1980). Physiol. Behav. 25, 543 .

McLaughlin, C. L., Peikin, S. R. \& Baile, C. A. (1983). Am. Y. Physiol. (In the Press.)

McLean, S. \& Hoebel, B. G. (1980). Soc. Neurosci. Abst. 6, 532.

Maddison, S. (1977). Physiol. Behav. 19, 8 rg.

Mandenoff, A., Fumeron, F., Apfelbaum, M. \& Margules, D. L. (1982). Science 215, 1536.

Margules, D. L., Goldman, B. \& Finck, A. (1979). Brain Res. Bull. 4, 721.

Margules, D. L., Moisset, B., Lewis, M. J., Shibuya, H. \& Pert, C. B. (1978). Science 202, 988.

Martin, J. R. \& Novin, D. (1977). Physiol. Behav. 19, 46 r.

Mayer, J. (1955). Ann. N.Y. Acad. Sci. 63, 15.

Mendel, V. E., Sturdevant, R. A. L. \& Elashoff, J. (1980). Physiol. Behav. 24, 629.

Morley, J. E. (1980). Life Sci. 27, 355.

Morley, J. E. \& Levine, A. S. (1980a). Science 209, 1259.

Morley, J. E. \& Levine, A. S. (1980b). Eur. F. Pharm. 67, 309.

Morley, J. E. \& Levine, A. S. (1981a). Life Sci. 29, 1901.

Morley, J. E. \& Levine, A. S. (1981 b). Pharm. Biochem. Behav. 14, 149.

Morley, J. E., Levine, A. S., Brown, D. M. \& Handwerger, B. S. (1982). Peptides 3, 17.

Morley, J. E., Levine, A. S., Grace, M. \& Kneip, J. (1982). Pharm. Biochem. Behav. 16, 701.

Morley, J. E., Levine, A. S., Hess, S. A., Brown, D. M. \& Handwerger, B. S. (Ig81). Soc. Neurosci. Abstr. 7, 854 .

Myers, R. D., Bender, S. A., Kistic, M. K. \& Brophy, P. D. (1972). Science 176, I 124.

Parrott, R. F. \& Baldwin, B. A. (1981). Physiol. Behav. 26, 419.

Parrott, R. F. \& Baldwin, B. A. (1982). Physiol. Behav. 28, 521 . 


\section{Vol. 42 Nutrient-hormone interactions in animal production}

Peikin, S. R., McLaughlin, C. L. \& Baile, C. A. (1982). Fedn Proc. Fedn Am. Socs exp. Biol. 4r, 388.

Perlow, M. J., Freed, W. J., Carman, J. S. \& Wyatt, R. J. (1980). Pharm. Biochem. Behav. I2, 609 .

Polak, J. M., Hobbs, S., Bloom, S. R., Solicia, E. \& Pearse, A. G. E. (1977). Lancet i, 972.

Pollard, H., Lorens, C., Schwarts, J. C., Gros, C. \& Dray, F. (1978). Brain Res. 151 , 392.

Porte, D. \& Woods, S. C. (1981). Diabetologia 20, 274.

Rayford, P. L., Schafmayer, A., Teichmann, R. K. \& Thompson, J. C. (1978). In Gut Hormones, p. 208 [S. R. Bloom and J. M. Polak, editors]. Edinburgh: Churchill Livingston.

Recant, L., Vogles, N. R., Luciano, M. \& Pert, C. B. (1980). Peptides 1, 309.

Rehfeld, J. F. (1978). Y. biol. Chem. 253, 4022.

Rehfeld, J. F., Goltermann, N., Larsson, L-I., Emson, P. M. \& Lee, C. M. (1979). Fedn Proc. Fedn Am. Socs exp. Biol. 38, 2325.

Riley, A. L., Zellner, D. A. \& Duncan, H. J. (1980). Neurosci. Biobehav. Rev. 4, 69.

Rizzo, A. J. \& Goltzman, D. (1981). Endocrinology 108, 1672.

Rossier, J., Rogers, J., Shibasaki, T., Guillemin, R. \& Bloom, F. E. (1979). Proc. natn. Acad. Sci. USA 76, 2077.

Saito, A., Sankaran, H., Goldfine, I. D. \& Williams, J. A. (1980). Science 208, I 55.

Sanger, D. J. (1981). Appetite 2, 193.

Sanger, D. J. \& McCarthy, P. S. (1981). Psychopharm. 74, 217.

Schulman, J. L., Carleton, J. L., Whitney, G. \& Whithorn, J. C. (1957). J. Appl. Physiol. 11, 419 .

Schulz, R., Wuster, M. \& Herz, A. (1980). Eur. F. Pharmacol. 63, 313.

Seoane, J. R., McLaughlin, C. L. \& Baile, C. A. (1975). F. Dairy Sci. 58, 349.

Smith, G. P. \& Gibbs, J. (I981). In Neurosecretion and Brain Peptides, p. $3^{89}$ [J. B. Martin, S. Reichlin and K. L. Bick, editors]. New York: Raven Press.

Smith, G. P., Jerome, C., Cushin, B. J., Eterno, R. \& Simansky, K. J. (I98 I). Science 213, 1036.

Smith, G. P., Jerome, C. \& Gibbs, J. (1981). Peptides 2, 409.

Steigerwalt, R. W. \& Williams, J. A. (1981). Endocrinology 109, 1746.

Stern, J. J., Cudillo, C. A. \& Kruper, J. (1976). F. comp. Physiol. Psychol. 90, $4^{84}$.

Straus, E. \& Yalow, R. S. (1979). Science $203,69$.

Straus, E. \& Yalow, R. S. (1980). Life Sci. 23, 969.

Talmage, R. V., Doppelt, S. H. \& Cooper, C. W. (1975). Proc. Soc. exp. biol. Med. 149, 855.

Tepperman, F. S., Hirst, M. \& Gowdey, C. W. (1981). Soc. Neurosci. Abstr. 7, 384.

Terenius, L. (1978). Ann. Rev. Pharmacol. Toxicol. 18, i89.

Urwyler, S. \& Tabakoff, B. (1981). Life Sci. 28, 2277.

Walsh, J. H., Lamers, C. B. \& Valenzuela, J. E. (1982). Gastroenterology 82, 438.

West, D. B., Williams, R. H., Braget, D. J. \& Woods, S. C. (1982). Peptides 3, 6r.

Woods, S. C., Decke, E. \& Vasselli, J. R. (1974). Psychol. Rev. $81,26$.

Woods, S. C., Lotter, E. C., McKay, L. D. \& Porte, D. (1979). Nature, Lond. 282, 503.

Yim, G. K. W., Lowy, M. T., Holsapple, M. P. \& Nichols, M. D. (1980). Soc. for Neurosci. Abstr. 6, 528 . 